Revistade
Economid
Contemporâned

\title{
TIPOS DE COMMODITIES, TAXA DE CÂMBIO E CRESCIMENTO ECONÔMICO: EVIDÊNCIAS DA MALDIÇÃO DOS RECURSOS NATURAIS PARA O BRASIL
}

\author{
Michele Polline Veríssimo ${ }^{a}$ \\ Clésio Lourenço Xavier ${ }^{b}$ \\ ${ }^{\text {a }}$ Professora adjunta do Instituto de Economia da Universidade Federal de Uberlândia (IE-UFU). \\ ${ }^{\mathrm{b}}$ Professor associado do IE-UFU e pesquisador do CNPq.
}

Artigo recebido em 29/11/2012 e aprovado em 06/10/2014.

\begin{abstract}
RESUMO: A literatura sobre a maldição dos recursos naturais argumenta que a especialização das exportações em commodities acarreta menores taxas de crescimento econômico. Este trabalho sugere que esse resultado depende do tipo de commodity analisada. Para isso, utiliza a metodologia de Vetores Autorregressivos e Funções de Resposta aos Impulsos para investigar a existência de efeitos negativos das exportações de alimentos, matérias-primas, minerais e energia sobre o crescimento econômico e a taxa de câmbio real brasileira, com base no período 2000-2011. Os resultados sinalizam alguma evidência da maldição dos recursos naturais no Brasil, uma vez que alimentos, matérias-primas e minerais contribuíram para explicar as menores taxas de crescimento econômico e a apreciação cambial. Todavia, tais evidências são fracas, pois ocorrem com alguma defasagem e têm curta duração.
\end{abstract}

PALAVRAS-CHAVE: Commodities; exportações; taxa de câmbio; crescimento; Brasil.

CLASSIFICAÇÃO JEL: F37; F17; O24.

Correspondência para Michale Polline Veríssimo.

E-mail: michele@ie.ufu.br. 


\section{TYPES OF COMMODITIES, EXCHANGE RATE AND ECONOMIC GROWTH: EVIDENCES FROM NATURAL RESOURCE CURSE FOR BRAZIL}

ABSTRACT: The natural resource curse literature argues that commodities exports promote lower economic growth rates. This paper suggests that this result depends on the type of commodity analyzed. This paper uses Vector Autoregressive and Impulse Response Functions to investigate the existence of negative effects between food, raw materials, minerals and energy exports on Brazilian economic growth and real exchange rate, based in period 2000-2011. The results indicate some evidence of the natural resources curse in Brazil, since food, raw materials and minerals contribute to explain the lower rates of economic growth and exchange rate appreciation. However, such evidence is weak because they occur with some lag and have short duration.

KEYWORDS: Commodities; exports; exchange rate; growth; Brazil.

\section{INTRODUÇÃO}

A literatura sobre a "maldição dos recursos naturais" (natural resource curse) parte do pressuposto de que as economias ricas em recursos naturais tendem a apresentar menores taxas de crescimento econômico. Neste contexto, a alta dos preços das commodities e a apreciação da taxa de câmbio real podem resultar em especialização das exportações em produtos intensivos em recursos naturais nas economias concentradas nos setores primários, prejudicando os setores produtores de bens manufaturados, com impactos perversos sobre a dinâmica de crescimento econômico. Assim, países ricos em recursos naturais, como Rússia, Nigéria e Venezuela, teriam apresentado, ao longo dos últimos séculos, taxas de crescimento do Produto Interno Bruto (PIB) comparativamente baixas; enquanto economias com recursos naturais limitados, tais como Japão, Hong Kong, Coreia, Singapura e Suíça, obtiveram taxas de crescimento consideravelmente mais altas.

A maldição dos recursos naturais está vinculada ao argumento de que o súbito aumento da renda decorrente da exploração daqueles recursos (derivado de um aumento dos preços destes produtos ou da descoberta de novas fontes) cria uma falsa ideia de segurança e enfraquece a necessidade percebida de investimento e de promoção de estratégias de crescimento. Nestes termos, países ricos em recursos naturais tendem a desenvolver políticas protecionistas, com burocracia e ineficiência na utilização dos recursos (fraqueza institucional), o que acarreta menores taxas de investimento, e, consequentemente, menor crescimento econômico. Além disso, a tendência secular de declínio da relação entre os preços das exportações dos produtos primários e dos manufaturados, e a maior elasticidade-renda da demanda por manufaturados também dificultam o crescimento baseado em recursos naturais. Considerando que os preços das commodities são mais voláteis, as economias dependentes destes recursos são mais instáveis, o que cria um ambiente de incerteza para os investidores em todos os setores da economia, desencorajando o investimento. Outra explicação para o problema se atrela à hipótese de que as atividades intensivas em recursos naturais propiciam menores efeitos de aprendizado e de difusão tecnológica do que as atividades industriais, sendo que as exportações dos bens manufaturados ficam prejudicadas pela apreciação da moeda local e pelas pressões inflacionárias resultantes do aumento da demanda doméstica. Finalmente, considera-se que, quando os setores intensivos em recursos naturais se expandem relativamente aos demais setores da economia, os retornos do capital humano decrescem e os investimentos em educação declinam, comprometendo o processo de desenvolvimento dos países no longo prazo (Sachs e Warner, 1995; Frankel, 2010; van der Ploeg, 2010).

Este trabalho investiga as relações entre exportações de commodities (alimentos, matérias-primas, minerais e energia), taxa de câmbio e crescimento econômico. Neste 
contexto, busca-se analisar se as exportações de commodities pela economia brasileira têm contribuído para um menor crescimento econômico e para a ocorrência de uma taxa de câmbio real apreciada. A hipótese é a que algumas commodities podem ser mais favoráveis à ocorrência da maldição dos recursos naturais do que outras. Em outras palavras, acredita-se que existam diferentes efeitos das diversas commodities exportadas sobre o comportamento do câmbio e do crescimento econômico, o que dificulta a obtenção de evidências deste problema quando se utiliza indicadores agregados para as exportações de commodities.

Além desta introdução, o trabalho está estruturado em cinco seções. A seção 2 realiza uma breve revisão da literatura sobre a relação entre abundância de recursos naturais e crescimento econômico. A seção 3 descreve o perfil do comércio brasileiro de commodities no período 2000-2011. A seção 4 apresenta o modelo empírico com base na metodologia de Vetores Auto-Regressivos (VAR) utilizado para identificar os efeitos das exportações das diversas commodities sobre o crescimento econômico e a taxa de câmbio real. A seção 5 discute os resultados obtidos. Por fim, a seção 6 sistematiza as principais conclusões obtidas.

\section{ABUNDÂNCIA DE RECURSOS NATURAIS E CRESCIMENTO ECONÔMICO}

A relação entre a abundância de recursos naturais e o crescimento econômico tem sido bastante discutida pela literatura econômica, emergindo algumas explicações para a ocorrência (ou não) do problema a partir da obtenção de diversos resultados empíricos que serão sintetizados brevemente a seguir.

O trabalho pioneiro sobre a maldição dos recursos naturais é o de Sachs e Warner (1995). Estes autores desenvolvem um modelo endógeno de crescimento cross-country que investiga a relação entre exportações baseadas em recursos naturais e taxa de crescimento do PIB no período 1970-1989, e obtêm que uma participação mais elevada das exportações de produtos primários está associada a menores taxas de crescimento econômico. Em extensão, Sachs e Warner (2001) afirmam que, mesmo quando outras variáveis de controle (crescimento passado, relação entre grau de abertura e renda inicial, variáveis políticas e variáveis geográficas) são adicionadas nas regressões, ainda se observa uma relação negativa entre a abundância de recursos naturais e o crescimento econômico. Também se obtém que países ricos em recursos naturais apresentam níveis gerais de preços mais elevados e menor contribuição das exportações de manufaturados sobre o crescimento.

Papyrakis e Gerlagh (2004) encontram evidências de que os recursos naturais têm um impacto negativo sobre o crescimento, porém, possuem um efeito positivo se ou- tras variáveis explicativas forem incluídas na análise, tais como corrupção, investimento, grau de abertura, escolaridade, termos de troca.

Cardoso e Holland (2009) argumentam que a maldição dos recursos naturais e a incapacidade da América do Sul de se integrar explicam as menores taxas de crescimento econômico desta região quando comparado ao Leste Asiático. Este resultado se baseia na apreciação da taxa de câmbio real decorrente das exportações baseadas em recursos naturais, investimento insuficiente em educação, fraqueza das instituições, altos gastos públicos, e volatilidade dos preços dos principais produtos exportados.

Alguns estudos enfatizam que os problemas associados à dependência dos recursos naturais são políticos, dada a incapacidade da sociedade em lidar com as altas receitas derivadas da exploração dos recursos naturais, gerando ineficiência e atitudes rent-seeking. Também ressaltam que a exploração de certos tipos de commodities seria mais propícia à geração de ineficiências, com impactos diferentes sobre o crescimento.

Nesta direção, Murshed (2004) afirma que certos tipos de recursos naturais, como petróleo e minerais, tendem a gerar uma concentração de receitas, retardando o desenvolvimento institucional e promovendo o comportamento rent-seeking. $\mathrm{O}$ autor estima um modelo em painel que considera os efeitos da qualidade institucional ligada à posse do tipo de recurso natural sobre o crescimento econômico. Os resultados obtidos sugerem que países ricos em petróleo e minerais têm piores instituições, o que causa um desempenho econômico menor se comparado aos países abundantes em bens agrícolas exportáveis.

Mehlum et al. (2006) encontram evidências de que a natureza das instituições é fundamental para a existência da maldição dos recursos naturais, em que a relação inversa entre abundância de recursos naturais (especialmente quando se utiliza como medida desta a posse de recursos minerais) e crescimento econômico se verifica apenas para países com instituições inferiores.

Collier e Golderis (2007) investigam os efeitos dos preços das commodities agrícolas e não agrícolas sobre o crescimento econômico para 130 países no período 19632003. Os autores perceberam que os preços das commodities têm efeitos positivos sobre o crescimento no curto prazo explicados pelos ganhos de renda real em função da melhoria dos termos de troca. Porém, estes efeitos tornam-se negativos no longo prazo e estão restritos às commodities não agrícolas (petróleo e minerais), assim como em países com instituições fracas.

A partir de uma amostra de países conforme a intensidade de recursos naturais em alimentos, matérias-primas, minerais e combustíveis, Pessoa (2008) obtém que um aumento da participação daquelas variáveis no total exportado prejudica o crescimento do PIB per capita. A adição de uma medida de qualidade institucional nas esti- 
mações revela que boas instituições melhoram o crescimento, mas os efeitos das exportações das commodities sobre o produto continuam negativos.

Em contraponto, existe a defesa de que a posse de recursos naturais pode ser positiva para o desempenho econômico, uma vez que a exploração destes recursos constitui fonte de riqueza e renda, que, em parte, pode ser poupada ou convertida em capital para suportar aumentos futuros do produto. Desta forma, muitos países ricos em recursos naturais utilizaram suas receitas para desenvolver as atividades industriais, contribuindo para a obtenção de patamares mais elevados de crescimento econômico.

Stijns (2001) observa que se os setores intensivos em recursos naturais forem desenvolvidos por meio de formas avançadas de conhecimento, as externalidades positivas obtidas podem ser tão fortes quanto aquelas verificadas na atividade manufatureira, favorecendo o crescimento econômico.

Em linha, Rocha (2010) obtém efeitos negativos das exportações baseadas em recursos naturais sobre o crescimento econômico, mas quando se introduz o efeito do crescimento das exportações, os resultados sugerem uma relação positiva entre as exportações baseadas em recursos naturais e o crescimento do produto. Também são obtidas evidências de que os efeitos de produtividade e spillovers dos setores baseados em recursos naturais são tão altos quanto nos setores exportadores de bens manufaturados.

Lederman e Malloney (2008) contestam os modelos que demonstraram uma relação negativa entre abundância de recursos naturais e crescimento econômico pelo argumento de que as medidas utilizadas para captar a abundância em fatores naturais são inadequadas. Assim, utilizando a razão exportações líquidas de bens intensivos em recursos naturais por trabalhador e medidas de qualidade institucional, verifica-se que os fatores naturais podem ter um efeito positivo sobre o crescimento, superando as evidências da maldição dos recursos naturais. Para os autores, os fatores limitadores do crescimento econômico não estão exclusivamente associados à existência de recursos naturais abundantes nos países, podendo ser relacionados a outras questões econômicas.

A literatura também ressalta os efeitos da especialização das economias em bens intensivos em recursos naturais sobre o comportamento da taxa de câmbio real (Doença Holandesa), com efeitos sobre o crescimento econômico de longo prazo.

O modelo de Doença Holandesa desenvolvido por Corden e Neary (1982) e aprimorado em Corden (1984) especifica a existência de três setores: o setor em expansão (booming sector), o setor que cresce lentamente e o setor de não comercializáveis. A ampliação do setor em expansão (derivada de progresso técnico, da descoberta de recursos, ou de mudança nos preços dos produtos do setor) aumenta a renda agregada dos fatores empregados e acarreta dois efeitos. O primeiro é o efeito de gastos, que surge quando parte da renda extra do setor em expansão é gasta no setor de não comercializáveis, o que aumenta a demanda e eleva o preço destes bens em relação aos preços dos comercializáveis, apreciando a taxa de câmbio real. O segundo é o efeito de deslocamento dos recursos, pois o setor em expansão requer mais trabalho e eleva a sua remuneração neste setor, o que desloca recursos (capital e trabalho) dos outros setores da economia. Este fato reduz o produto nos setores de bens comercializáveis (manufaturados) e não comercializáveis, causando desindustrialização e novo aumento dos preços dos bens não comercializáveis, pressionando a taxa de câmbio para uma apreciação adicional.

Palma (2005) identifica quatro fontes de desindustrialização, incluindo um novo conceito da Doença Holandesa. A primeira fonte é definida como o declínio no emprego industrial quando os países atingem certo nível de renda per capita. A segunda é determinada pelo contínuo declínio da relação entre emprego industrial e renda per capita para países de renda média e alta em decorrência das mudanças no paradigma tecnológico, da realocação de parte do processo de produção (intensivo em mão de obra) para países em desenvolvimento e das políticas econômicas implementadas. A terceira consiste no declínio na renda per capita correspondendo ao ponto de virada da curva de regressão, sugerindo uma queda no tempo da relação de U invertido para países de renda média e alta. Por fim, tem-se a Doença Holandesa, situação em que os países registram uma queda no emprego industrial maior do que a esperada em função das três fontes anteriores. Esta desindustrialização adicional está associada tanto ao aumento repentino nas exportações de produtos primários como também ao desenvolvimento de um setor bem-sucedido de exportação e serviços (turismo e finanças). Desta forma, a Doença Holandesa é um processo pelo qual o país passa a necessitar de superávit comercial em serviços ou produtos primários. Palma (2005) também sugere que a desindustrialização nos países latino-americanos está relacionada às mudanças na política econômica (liberalização comercial e financeira) nos anos 1990 que levaram as economias a deixarem de induzir seus processos de industrialização pela política de substituição de importações para retornarem à posição ricardiana natural associada a vantagens comparativas de acordo com a abundância de recursos tradicionais.

Bresser-Pereira (2009) também argumenta que a abundância de recursos naturais baratos pode promover uma especialização da economia em commodities em decorrência da obtenção de rendas ricardianas proporcionadas pelas vantagens comparativas destes produtos em relação aos concorrentes internacionais. As divisas obtidas pelas vendas externas destes bens mantêm a taxa de câmbio real em patamares apreciados vis-à-vis àqueles necessários para tornar rentáveis as exportações de bens manufaturados. Este processo culmina com uma transferência de recursos produtivos 
dos demais setores da economia para a produção de commodities, gerando desindustrialização e promovendo baixas taxas de crescimento do produto.

Em linhas gerais, as evidências sobre a relação entre especialização em recursos naturais e crescimento não são conclusivas. Neste sentido, a contribuição deste trabalho consiste em investigar se certos tipos de commodities podem ser mais favoráveis à ocorrência da maldição dos recursos naturais pela via dos efeitos sobre a taxa de câmbio real e o crescimento econômico a partir da avaliação do caso brasileiro no período 2000-2011.

\section{O COMÉRCIO BRASILEIRO DE COMMODITIES}

Entende-se por commodities os produtos intensivos em recursos naturais em estado bruto (primários) ou com pequeno grau de industrialização. Esta categoria envolve produtos agrícolas (em estado bruto e/ou industrializados), minerais (em estado bruto e/ou industrializados) e energia ${ }^{1}$. Estes produtos caracterizam-se pela produção padronizada e em grande quantidade, cujos preços são formados em bolsas de mercadorias no país ou no exterior. Desta forma, um produtor individual tem pouco ou nenhum controle sobre os preços destes bens, o que torna a liderança em custos a principal estratégia competitiva, sendo esta baseada na exploração de economias de escala e escopo, em ganhos de produtividade, na racionalização dos processos produtivos, no acesso aos recursos naturais, nas condições de infraestrutura e logística, entre outros (Nakahodo e Jank, 2006).

No caso brasileiro, considera-se que os produtos classificados como commodities, em função de suas vantagens comparativas que impactam sobre a produtividade e implicam na geração de rendas ricardianas, poderiam propiciar a maldição dos recursos naturais, na medida em que a melhoria da rentabilidade destes bens promove o deslocamento de recursos produtivos (capital, trabalho e tecnologia) dos demais setores da economia para a produção de bens intensivos em recursos naturais, causando menor produção de bens manufaturados e, consequentemente, menores taxas de crescimento para o país.

Para retratar o comportamento da pauta comercial de commodities negociadas pela economia brasileira no período recente, o Gráfico 1 apresenta o comportamento da participação das exportações deste tipo de bens vis-à-vis aos bens manufaturados entre 2000-2011.

Classificação adotada pelo trabalho de Bresser-Pereira e Marconi (2007).
Gráfico 1 - Participação das commodities e dos produtos manufaturados nas exportações brasileiras no período $2000-2011$ (em \%)

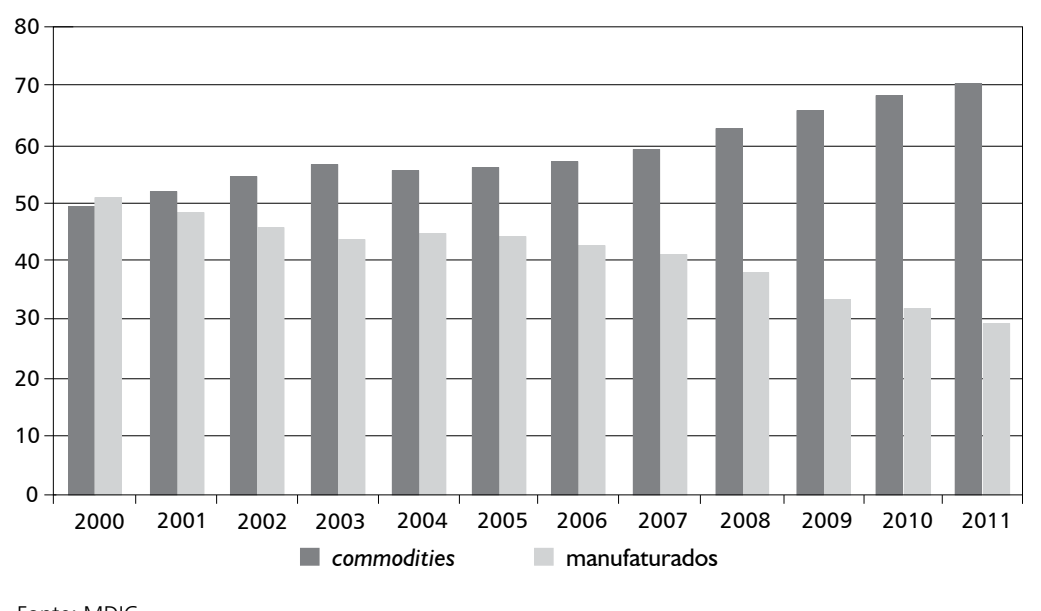

Fonte: MDIC.

Os dados revelam uma participação crescente das commodities nas vendas externas do país, passando de 49,3\% em 2000 para 70,9\% em 2011, contando, portanto, com um aumento de participação de 21,6 p.p. Por outro lado, verifica-se uma perda de participação quase contínua nas exportações dos produtos manufaturados no período, de 50,7\% em 2000 para $29,1 \%$ em 2011 . Este cenário assinala um processo de especialização da estrutura exportadora em bens intensivos em recursos naturais, em que o país é dotado de vantagens comparativas, em conjunto com um contexto de preços e demanda externa favoráveis para este tipo de produto. Ademais, percebe-se que as vendas externas de commodities foram independentes do patamar vigente da taxa de câmbio real, apresentando elevação, inclusive, no período de câmbio mais apreciado (2003 em diante). Há que se ressaltar que o desempenho das commodities brasileiras (em termos da participação nas exportações) não foi afetado pelo contexto da crise financeira internacional de 2008/2009.

O Gráfico 2 exibe a evolução do saldo comercial das commodities no período 2000-2011. Observa-se que este saldo foi superavitário e cresceu continuamente ao longo do período, especialmente, a partir de 2002, favorecido pelo aumento expressivo das exportações mediante o contexto de preços internacionais elevados, crescimento da demanda mundial, com destaque para a economia chinesa e apreciação da taxa de câmbio real. Em 2009, apesar de o valor das exportações de commodities ter caído em decorrência dos efeitos da crise internacional, estas permaneceram em níveis relativamente elevados (superiores aos observados em 2007) e se recuperaram rapidamente, 
atingindo o pico em 2011 (US\$181,5 bilhões). Embora as importações de commodities também tenham aumentado após 2005, verifica-se que tal aumento não foi suficiente para comprometer o desempenho do saldo comercial deste tipo de produto. Em 2011, o saldo comercial das commodities atingiu patamar recorde, com um valor de US\$ 108,7 bilhões.

\section{Gráfico 2 - Saldo comercial das commodities no período 2000-2011 (em US\$ milhões)}

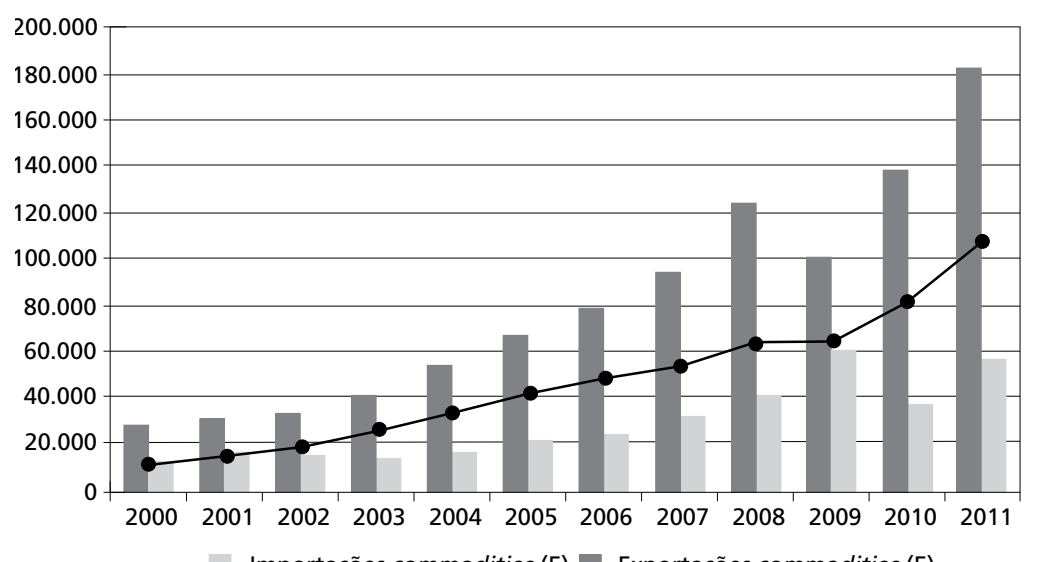

Importações commodities (E) — Exportações commodities (E)

$\longrightarrow$ Saldo commodities (E)

Fonte: MDIC.

A Tabela 1 apresenta o desempenho das commodities brasileiras no período 20002011 conforme o tipo de produto exportado: alimentos, matérias-primas, minerais e energia.

Alimentos e minerais constituíram os itens de maior peso na pauta exportadora de commodities no período, com participações médias de $22,5 \%$ e $20,5 \%$, respectivamente. Em seguida, as matérias-primas e as commodities energéticas possuíram participações médias de 9,2\% e 6,7\%, respectivamente. Estes dados caracterizam uma pauta de exportações de commodities relativamente diversificada no Brasil.

Todas as commodities ganharam peso nas exportações brasileiras no período. As commodities energéticas contaram com um aumento de participação mais expressivo (8,8 p.p.) na pauta exportadora. Os minerais computaram um aumento de participação de 7,1 p.p. no conjunto das exportações, seguidos pelos alimentos (ganho de 4,55 p.p.) e pelas matérias-primas, com participação mais estável (ganho de 1,16 p.p.). O comportamento exportador destas commodities pode ser explicado pelo contexto de preços internacionais elevados do petróleo e dos minerais, além da demanda bastante favorável para estes tipos de produtos, ocasionada pelo excepcional ritmo de crescimento da China na década de 2000, que se manteve mesmo com a crise internacional, além da maior demanda externa por alimentos e matérias-primas.

Tabela 1 - Participação dos tipos de commodities nas exportações brasileiras no período 2000-2011 (em \%)

\begin{tabular}{cccccc}
\hline Ano & Total & Alimentos & Matérias-primas & Minerais & Energia \\
\hline 2000 & 49,29 & 19,26 & 8,80 & 19,58 & 1,65 \\
2001 & 51,95 & 22,80 & 8,85 & 16,71 & 3,59 \\
2002 & 54,51 & 22,75 & 9,01 & 17,86 & 4,89 \\
2003 & 56,40 & 22,69 & 10,43 & 18,09 & 5,19 \\
2004 & 55,53 & 22,29 & 9,68 & 18,98 & 4,58 \\
2005 & 55,92 & 21,16 & 8,45 & 20,31 & 6,00 \\
2006 & 57,45 & 20,83 & 7,91 & 21,01 & 7,70 \\
2007 & 58,95 & 22,03 & 8,04 & 20,60 & 8,28 \\
2008 & 62,42 & 21,87 & 9,15 & 21,96 & 9,44 \\
2009 & 66,32 & 26,37 & 11,30 & 19,72 & 8,93 \\
2010 & 68,40 & 24,63 & 9,38 & 24,56 & 9,83 \\
2011 & 70,88 & 23,81 & 9,96 & 26,66 & 10,46 \\
\hline
\end{tabular}

Fonte: MDIC.

O Gráfico 3 apresenta o comportamento dos preços de alimentos, matérias-primas, minerais e combustíveis no período 2000-2011.

As diversas commodities tiveram preços crescentes na década de 2000, com exceção de 2009, época em que a crise internacional promoveu uma queda dos preços destes bens. Todavia, os preços se recuperaram rapidamente, retomando a trajetória ascendente e alcançando patamares superiores aos valores pré-crise. Há que se destacar os preços mais elevados dos minerais e das commodities energéticas, explicado pelo "Efeito China" decorrente do rápido e expressivo crescimento da demanda chinesa por tais tipos de bens, que são insumos da produção industrial.

A Tabela 2 ilustra o comportamento dos principais produtos exportados pelo Brasil ao longo da última década (em ordem decrescente conforme os valores observados em 2011).

Observa-se que, dentre os 15 principais produtos exportados em 2011, 12 podem ser classificados como commodities. Dentre estas, os minérios de ferro e seus concen- 
trados foram os produtos mais bem colocados, com um peso de $16,3 \%$ no total exportado pelo país, e com um aumento de 10,8 p.p. de participação na pauta exportadora entre 2000 e 2011 . Óleos brutos de petróleo (8,15 p.p.), soja mesmo triturada $(2,41$ p.p.), açúcar de cana em estado bruto (3,13 p.p.), e óleos combustíveis (1,00 p.p.) também ganharam maior relevância no conjunto das exportações brasileiras no período, o que justifica o bom desempenho dos itens de energia e minerais. As carnes (frango e bovina) contaram com um ligeiro aumento de participação nas vendas externas $(1,30$ p.p. e 0,72 p.p., respectivamente), café cru em grão teve um ganho de 0,29 p.p. e o açúcar refinado ganhou 0,53 p.p. de participação na pauta exportadora. Outras commodities perderam participação na pauta no período, em que se destacam farelos e resíduos da extração de óleo de soja (-0,77 p.p.) e pastas químicas de madeira (-0,96 p.p.).

\section{Gráfico 3 - Preços das commodities no período 2000-2011}

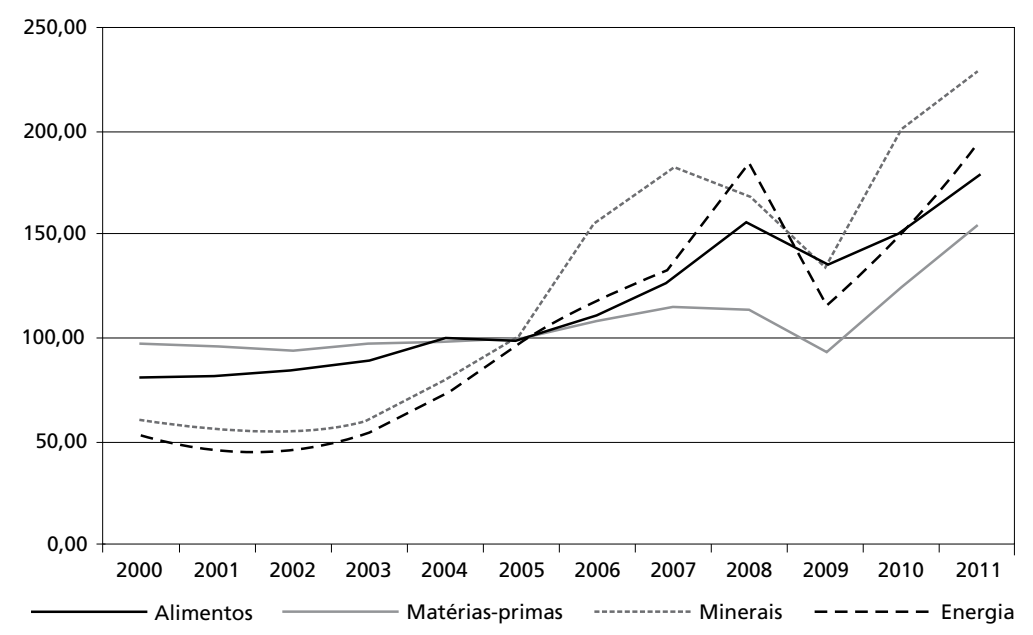

Nota: Indice $2005=100$

Fonte: IME

Há que se ressaltar que, dentre os 15 principais produtos exportados no período, apenas os itens automóveis de passageiros ( $10^{\mathrm{a}}$ posição), partes e peças para veículos automotores e tratores ( $12^{\mathrm{a}}$ posição), e aviões ( $13^{\mathrm{a}}$ posição) constituíram produtos dos setores de bens manufaturados (segmento de máquinas e equipamentos de transporte). Todavia, todos estes itens perderam participação nas vendas externas: aviões (-4 p.p.), partes e peças para veículos automotores e tratores (-0,63 p.p.), e automóveis de passageiros (-1,5 p.p.). Portanto, reafirma-se a importância das commodities para o resultado comercial da economia brasileira nos últimos anos. Ademais, pode-se cons- tatar um aumento do peso relativo deste conjunto de bens na pauta exportadora brasileira, uma vez que tais produtos somavam $36,66 \%$ de participação nas vendas externas em 2000 e passaram para 56,75\% em 2011 (aumento de 20,1 p.p.).

Tabela 2 - Participação de commodities selecionadas na pauta exportadora brasileira no período $2000-2011$ (em \%)

\begin{tabular}{lllll}
\hline Produtos & 2000 & 2005 & 2011 & $(2011-2000)$ \\
\hline 1. Minérios de ferro e seus concentrados & 5,53 & 6,17 & 16,33 & 10,80 \\
2. Óleos brutos de petróleo & 0,29 & 3,52 & 8,44 & 8,15 \\
3. Soja mesmo triturada & 3,97 & 4,52 & 6,38 & 2,41 \\
4. Açúcar de cana, em estado bruto & 1,38 & 2,01 & 4,51 & 3,13 \\
5. Café cru em grão & 2,83 & 2,13 & 3,12 & 0,29 \\
6. Carne de frango congelada, fresca, refrig. incl. miúdos & 1,46 & 2,81 & 2,76 & 1,30 \\
7. Farelo e resíduos da extração de óleo de soja & 3,00 & 2,42 & 2,23 & $-0,77$ \\
8. Pastas químicas de madeira & 2,91 & 1,72 & 1,95 & $-0,96$ \\
9. Produtos semimanufaturados de ferro ou aço & 2,47 & 1,92 & 1,81 & $-0,66$ \\
10. Automóveis de passageiros & 3,21 & 3,72 & 1,71 & $-1,50$ \\
11. Carne de bovino congelada, fresca, refrigerada & 0,91 & 2,04 & 1,63 & 0,72 \\
12. Partes e peças para véculos automóveis e tratores & 2,19 & 2,08 & 1,56 & $-0,63$ \\
13. Aviooes & 5,54 & 2,68 & 1,53 & $-4,01$ \\
14. Óleos combustíveis (óleo diesel, fuel-oil, etc.) & 0,47 & 1,33 & 1,47 & 1,00 \\
15. Açúcar refinado & 0,79 & 1,30 & 1,32 & 0,53 \\
Total dos produtos & 36,66 & 40,37 & 56,75 & 20,09 \\
\hline
\end{tabular}

Fonte: MDIC.

A Tabela 3 exibe os três principais mercados de destino das exportações brasileiras (para os 15 principais produtos vendidos) no período 2000-2011. Os dados sinalizam o papel assumido pela China, Estados Unidos (EUA) e diversos países europeus enquanto principais demandantes dos produtos oferecidos pelo Brasil ao longo da década.

Merece destaque a China enquanto compradora de commodities minerais, pois o país passou a adquirir $47 \%$ das vendas totais de minérios de ferro e seus concentrados em 2011 (em 2000, as compras de minérios de ferro pela China equivaliam a 8,8\% das vendas deste produto). Em 2011 este país também ganhou relevância nas vendas brasileiras de soja mesmo triturada, óleos brutos de petróleo, açúcar, pastas químicas de madeira e aviões. De outro lado, os EUA foram compradores proeminentes de óleos brutos de petróleo, café cru em grãos, produtos semimanufaturados de ferro e aço, pasta química de madeira, partes e peças para automóveis e tratores, e aviões. 
Tabela 3 - Principais compradores dos produtos exportados pelo Brasil (em \%)

\begin{tabular}{|c|c|c|c|c|}
\hline Produto & Compradores & 2000 & Compradores & 2011 \\
\hline \multirow{4}{*}{$\begin{array}{l}\text { Minérios de ferro e seus } \\
\text { concentrados }\end{array}$} & Total & 5,53 & Total & 16,33 \\
\hline & Japão & 0,83 & China & 7,73 \\
\hline & Alemanha & 0,78 & Japão & 1,72 \\
\hline & China & 0,49 & Holanda & 0,79 \\
\hline \multirow[t]{4}{*}{ Óleos brutos de petróleo } & Total & 0,29 & Total & 8,44 \\
\hline & Argentina & 0,20 & Estados Unidos & 2,26 \\
\hline & Santa Lúcia & 0,09 & China & 1,91 \\
\hline & Emirados Árabes & 0 & Santa Lúcia & 1,15 \\
\hline \multirow[t]{4}{*}{ Soja mesmo triturada } & Total & 3,97 & Total & 6,38 \\
\hline & Holanda & 1,19 & China & 4,28 \\
\hline & China & 0,61 & Espanha & 0,47 \\
\hline & Espanha & 0,40 & Holanda & 0,28 \\
\hline \multirow[t]{4}{*}{ Açúcar de cana, em estado bruto } & Total & 1,38 & Total & 4,51 \\
\hline & Rússia & 0,53 & Rússia & 0,72 \\
\hline & Estados Unidos & 0,13 & China & 0,45 \\
\hline & Emirados Árabes & 0,12 & Egito & 0,34 \\
\hline \multirow[t]{4}{*}{ Café cru em grão } & Total & 2,83 & Total & 3,12 \\
\hline & Alemanha & 0,49 & Estados Unidos & 0,70 \\
\hline & Estados Unidos & 0,40 & Alemanha & 0,65 \\
\hline & Itália & 0,32 & Itália & 0,30 \\
\hline \multirow{4}{*}{$\begin{array}{l}\text { Carne de frango congelada, fresca } \\
\text { ou refrig. incl. miúdos }\end{array}$} & Total & 1,46 & Total & 2,76 \\
\hline & Arábia Saudita & 0,31 & Japão & 0,52 \\
\hline & Japão & 0,22 & Arábia Saudita & 0,47 \\
\hline & Hong Kong & 0,11 & Hong Kong & 0,22 \\
\hline \multirow{4}{*}{$\begin{array}{l}\text { Farelo e resíduos da extração de } \\
\text { óleo de soja }\end{array}$} & Total & 3,00 & Total & 2,23 \\
\hline & França & 0,75 & Holanda & 0,64 \\
\hline & Holanda & 0,75 & França & 0,30 \\
\hline & Bélgica & 0,17 & Alemanha & 0,22 \\
\hline \multirow[t]{4}{*}{ Pastas químicas de madeira } & Total & 2,91 & Total & 1,95 \\
\hline & Estados Unidos & 0,78 & China & 0,51 \\
\hline & Bélgica & 0,53 & Holanda & 0,41 \\
\hline & Japão & 0,36 & Estados Unidos & 0,36 \\
\hline \multirow{4}{*}{$\begin{array}{l}\text { Produtos semimanufaturados de } \\
\text { ferro ou aço }\end{array}$} & Total & 2,47 & Total & 1,81 \\
\hline & Estados Unidos & 0,99 & Estados Unidos & 0,67 \\
\hline & Bélgica & 0,35 & Alemanha & 0,26 \\
\hline & Coreia do Sul & 0,24 & Coreia do Sul & 0,25 \\
\hline
\end{tabular}

Tabela 3 - Principais compradores dos produtos exportados pelo Brasil (em \%)

\begin{tabular}{|c|c|c|c|c|}
\hline Produto & Compradores & 2000 & Compradores & 2011 \\
\hline Automóveis de passageiros & $\begin{array}{l}\text { Total } \\
\text { México } \\
\text { Argentina } \\
\text { Estados Unidos }\end{array}$ & $\begin{array}{l}3,21 \\
0,92 \\
0,77 \\
0,54\end{array}$ & $\begin{array}{l}\text { Total } \\
\text { Argentina } \\
\text { México } \\
\text { Alemanha }\end{array}$ & $\begin{array}{l}1,71 \\
1,41 \\
0,15 \\
0,04\end{array}$ \\
\hline $\begin{array}{l}\text { Carne bovina congelada, fresca } \\
\text { ou refrigerada }\end{array}$ & \begin{tabular}{|l} 
Total \\
Holanda \\
Chile \\
Egito
\end{tabular} & $\begin{array}{l}0,91 \\
0,18 \\
0,10 \\
0,01\end{array}$ & $\begin{array}{l}\text { Total } \\
\text { Rússia } \\
\text { Irã } \\
\text { Egito }\end{array}$ & $\begin{array}{l}1,63 \\
0,40 \\
0,27 \\
0,16\end{array}$ \\
\hline $\begin{array}{l}\text { Partes e peças para vé́culos } \\
\text { automóveis e tratores }\end{array}$ & \begin{tabular}{|l|} 
Total \\
Estados Unidos \\
Argentina \\
México
\end{tabular} & $\begin{array}{l}2,19 \\
0,75 \\
0,61 \\
0,19\end{array}$ & $\begin{array}{l}\text { Total } \\
\text { Argentina } \\
\text { Estados Unidos } \\
\text { México }\end{array}$ & $\begin{array}{l}1,56 \\
0,87 \\
0,15 \\
0,11\end{array}$ \\
\hline Aviôes & \begin{tabular}{|l|} 
Total \\
Estados Unidos \\
França \\
Reino Unido
\end{tabular} & $\begin{array}{l}5,54 \\
3,09 \\
0,67 \\
0,39\end{array}$ & $\begin{array}{l}\text { Total } \\
\text { Estados Unidos } \\
\text { China } \\
\text { Argentina }\end{array}$ & $\begin{array}{l}1,53 \\
0,25 \\
0,24 \\
0,16\end{array}$ \\
\hline $\begin{array}{l}\text { Óleos combustíveis (óleo diesel, } \\
\text { "fuel-oil", etc.) }\end{array}$ & \begin{tabular}{|l} 
Total \\
$\quad$ Estados Unidos \\
Antilhas Holandesas \\
Cingapura
\end{tabular} & $\begin{array}{l}0,47 \\
0,15 \\
0,10 \\
0,02\end{array}$ & $\begin{array}{l}\text { Total } \\
\text { Holanda } \\
\text { Antilhas Holandesas } \\
\text { Cingapura }\end{array}$ & $\begin{array}{l}1,47 \\
0,34 \\
0,32 \\
0,31\end{array}$ \\
\hline Açúcar refinado & \begin{tabular}{|l} 
Total \\
$\quad$ Nigéria \\
Egito \\
Emirados Árabes
\end{tabular} & $\begin{array}{l}0,79 \\
0,18 \\
0,10 \\
0,07\end{array}$ & $\begin{array}{l}\text { Total } \\
\text { Emirados Árabes unidos } \\
\text { Gana } \\
\text { Arábia Saudita }\end{array}$ & $\begin{array}{l}1,32 \\
0,19 \\
0,10 \\
0,08\end{array}$ \\
\hline
\end{tabular}

Fonte: MDIC.

O Gráfico 3 ilustra a participação da China, União Europeia e EUA nas aquisições de produtos básicos negociados pelo Brasil no período 2000-2011. Mais uma vez, os dados denotam a importância assumida pela China no comércio brasileiro de bens intensivos em recursos naturais, sendo que esta passa a comprar $32,15 \%$ das commodities básicas exportadas pelo Brasil em 2011; seguida pela União Europeia, que embora tenha reduzido sua participação, ainda adquire $22,4 \%$ dos produtos básicos vendidos pelo Brasil no mercado externo. Já os EUA mantiveram uma participação relativamente estável no conjunto das vendas de produtos básicos brasileiros $(7,13 \%)$. 
Gráfico 3 - Participação da China, EUA e União Europeia nas compras de commodities brasileiras no período 2000-2011 (em \%)

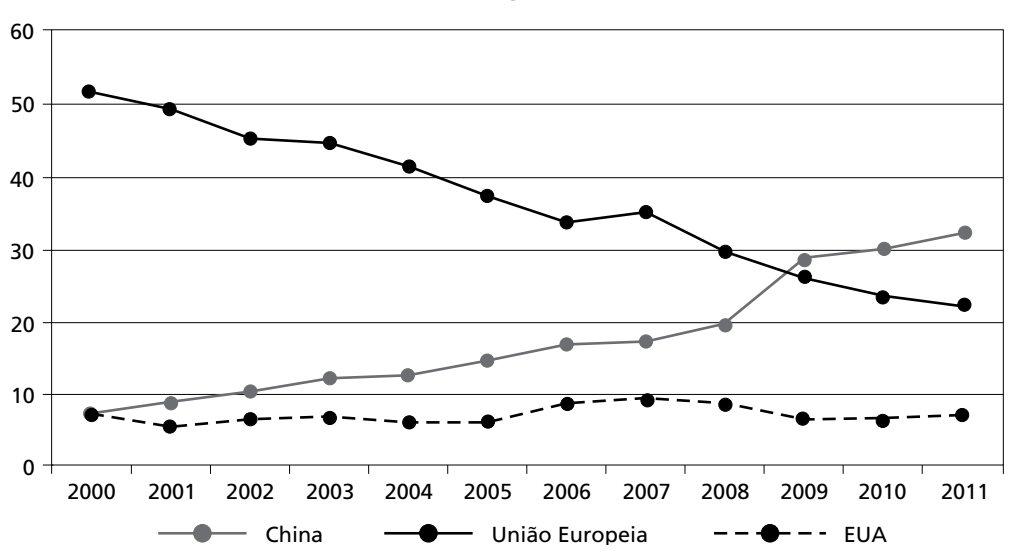

Fonte: MDIC.

Em termos gerais, a análise do perfil exportador da economia brasileira ao longo da década de 2000 sinaliza que as commodities tiveram um papel fundamental para explicar o bom desempenho do comércio internacional do país, atrelado a um cenário de preços elevados destes produtos e de uma demanda externa bastante favorável ligada especialmente aos resultados econômicos da China, que passou a constituir, junto com os EUA e a União Europeia, uma compradora relevante dos produtos brasileiros no mercado internacional.

\section{METODOLOGIA E FONTE DE DADOS}

Este trabalho se propõe a investigar os efeitos das exportações de alimentos, matérias-primas, minerais e energia sobre a taxa de câmbio real, e a contribuição das vendas externas destas commodities para explicar o crescimento econômico brasileiro. Parte-se da hipótese de que existem diferentes impactos dos vários tipos de commodities exportadas sobre o comportamento cambial e da taxa de crescimento do PIB, conforme ressaltam os trabalhos de Murshed (2004), Mehlum et al. (2006) e Collier e Golderis (2007). Ou seja, o desempenho de determinados bens pode ser mais favorável à ocorrência da maldição dos recursos naturais. No Brasil, nota-se que a pauta exportadora de commodities é nitidamente dominada por alimentos e minerais. De acordo com a literatura sobre a maldição dos recursos naturais, os efeitos perversos das exportações de commodities sobre o desempenho econômico verificam-se, sobretudo, em países exportadores de petróleo e minerais, em que as economias estariam propensas a desenvolver um comportamento rentista, com instituições mais fracas².

A metodologia de Vetores Auto-Regressivos (VAR) será adotada para avaliar os possíveis efeitos das exportações das diferentes commodities sobre a taxa de câmbio real e a taxa de crescimento do produto nacional com base no período 2000-2011. A metodologia VAR é utilizada para a construção de sistemas de previsão de séries temporais inter-relacionadas e para a análise dos impactos dinâmicos dos distúrbios aleatórios sobre o sistema de variáveis que compõem o modelo. No VAR, todas as variáveis analisadas são tratadas como endógenas, formando um sistema de equações estimadas por Mínimos Quadrados Ordinários (MQO), em que o valor de cada variável é expresso como uma função linear dos valores defasados dela mesma e de todas as outras variáveis incluídas no modelo. Assim, a metodologia VAR torna possível a investigação da interação de algumas variáveis explicativas do crescimento econômico e da taxa de câmbio real relacionadas à dinâmica do comércio dos diversos tipos de commodities, sem que se assuma previamente uma relação causal entre tais variáveis.

Os modelos VAR estimados encontram-se fundamentados na equação básica de determinação do produto nacional, expressa a seguir:

$$
Y=C+I+G+(X-M)
$$

Onde:

$Y=$ Produto nacional

$C=$ Consumo agregado

$I=$ Investimento agregado

$G=$ Gastos do governo

$(X-M)=$ Exportações líquidas

Assumindo que os impactos do consumo, investimento, gastos do governo e importações sobre o produto nacional sejam exógenos, os modelos VAR estimados intencionam captar os efeitos das exportações de alimentos, matérias-primas, minerais e energia sobre o crescimento do produto brasileiro, controlando os modelos pelos preços das commodities, taxa de câmbio e demanda externa.

2 Cabe ressaltar que os efeitos da qualidade institucional não serão tratados neste trabalho, tendo em vist que os dados sobre as instituições brasileiras possuem pouca variabilidade, o que compromete estatisticamente a análise empírica. 
A investigação será efetivada por meio da estimação do seguinte modelo:

$$
\text { Modelo VAR: TCPIB, XCOM }{ }_{i} \text { TCREF, IPCOM }, \text { YE }
$$

Onde:

TCPIB = Taxa de crescimento do produto real brasileiro (em \%)

TCREF = Taxa de câmbio real efetiva brasileira (índice $2005=100$ )

$\operatorname{IPCOM}_{i}=$ Preços de commodities, sendo $i=$ alimentos, matérias-primas, minerais e energia (índice $2005=100$ )

$\mathrm{XCOM}_{i}=$ Participação das exportações de commodities nas exportações totais do país, sendo $i=$ alimentos, matérias-primas, minerais e energia (em \%)

$Y E=$ Demanda externa (índice $2005=100$ )

A proxy para a variável demanda externa foi construída com base na taxa de crescimento do produto dos principais parceiros comerciais brasileiros - China, EUA e União Europeia - ponderada pelo peso destes parceiros nas vendas externas do Brasil.

Para a estimação dos modelos VAR propostos foram utilizados dados para o período 2000-T1 a 2011-T4 obtidos junto às estatísticas do Banco Central do Brasil (BCB), Ministério do Desenvolvimento, Indústria e Comércio Exterior (MDIC), Instituto Brasileiro de Geografia e Estatística (IBGE) e do banco de dados do Fundo Monetário Internacional (International Financial Statistics).

A partir dos modelos VAR, foram estimadas as Funções de Resposta aos Impulsos (FIR). A FIR traça o efeito de um choque no tempo $t$ dos termos de erro de uma variável particular sobre os valores correntes e futuros das variáveis do VAR, mantendo-se todos os outros choques constantes, tendo em vista que um choque para uma variável $y_{t}$ qualquer afeta essa mesma variável e é transmitido para todas as variáveis endógenas através da estrutura dinâmica do VAR (Stock e Watson, 2001; Enders, 2004).

\section{RESULTADOS E DISCUSSÃO}

\subsection{TESTES DE ESTACIONARIEDADE E SELEÇÃO DOS MODELOS VAR}

Dado que o VAR pressupõe a utilização de séries estacionárias, o diagnóstico da raiz unitária das séries utilizadas neste trabalho foi baseado na aplicação dos Testes Augmented Dickey-Fuller (ADF) e Phillips-Perron (PP). A Tabela 4 apresenta uma síntese dos resultados destes testes.
Tabela 4 - Testes de Raiz Unitária

\begin{tabular}{l|c|c|c|c|c|c}
\hline \multicolumn{1}{c|}{ Séries } & \multicolumn{3}{|c|}{ ADF } & \multicolumn{3}{|c}{ PP } \\
\hline Taxa de crescimento do PIB (TCPIB) & t-ADF & Defasagem & OI & t-PP & Bandwidth & II \\
Taxa câmbio real efetiva (TCREF) & $-4,17^{*}$ & 4 & $\mathrm{I}(0)$ & $-15,21^{*}$ & 14 & $\mathrm{I}(0)$ \\
Preços alimentos (IPAL) & $-7,59^{*}$ & 1 & $\mathrm{I}(\mathrm{I})$ & $-5,36^{*}$ & 19 & $\mathrm{I}(\mathrm{I})$ \\
Preços matérias-primas (IPMP) & $-5,85^{*}$ & 1 & $\mathrm{I}(1)$ & $-5,03^{*}$ & 25 & $\mathrm{I}(1)$ \\
Preços minerais (IPMIN) & $-5,37^{*}$ & 1 & $\mathrm{I}(1)$ & $-3,28^{* *}$ & 17 & $\mathrm{I}(1)$ \\
Preços energia (IPEN) & $-4,66^{*}$ & 0 & $\mathrm{I}(1)$ & $-4,35^{*}$ & 9 & $\mathrm{I}(1)$ \\
Exportações alimentos (XAL) & $-6,31^{*}$ & 1 & $\mathrm{I}(1)$ & $-6,08^{*}$ & 26 & $\mathrm{I}(1)$ \\
Exportações matérias-primas (XMP) & $-3,66^{*}$ & 0 & $\mathrm{I}(0)$ & $-3,66^{*}$ & 2 & $\mathrm{I}(0)$ \\
Exportações minerais (XMIN) & $-11,50^{*}$ & 2 & $\mathrm{I}(1)$ & $-6,05^{*}$ & 22 & $\mathrm{I}(0)$ \\
Exportações energia (XEN) & $-9,73^{*}$ & 0 & $\mathrm{I}(1)$ & $-13,15^{*}$ & 14 & $\mathrm{I}(1)$ \\
Demanda externa (YE) & $-6,98^{*}$ & 2 & $\mathrm{I}(1)$ & $-19,61^{*}$ & 17 & $\mathrm{I}(1)$ \\
\hline
\end{tabular}

Notas: (*) indica rejeição de $\mathrm{H}_{0}$ a $1 \%$ de significância estatística. $\left.{ }^{* *}\right)$ Indica rejeiçăo de $\mathrm{H}_{0}$ a $5 \%$ de significância estatística. Valores criticos do ADF e PP: $1 \%(-3,59)$ e $5 \%(-2,93)$. Ol indica a ordem de integração da série.
Fonte: Elaboraçăo própria com base nos resultados do Eviews 7 .

Dado que a hipótese nula dos testes ADF e Phillips-Perron se refere à existência de raiz unitária nas séries, os resultados indicaram a não rejeição da hipótese nula para as variáveis taxa de câmbio real efetiva; preços de alimentos, matérias-primas, minerais e energia; e exportações de minerais e de energia. Estas variáveis se tornaram estacionárias quando tomadas em primeira diferença, sendo integradas de ordem 1. Para taxa de crescimento do PIB, demanda externa, exportações de alimentos e de matérias-primas, os testes indicaram rejeição da hipótese nula de raiz unitária destas variáveis em nível, sugerindo que as mesmas são integradas de ordem zero³.

A partir da identificação da ordem de integração das séries, procedeu-se à especificação e escolha das defasagens dos modelos VAR, cujos resultados encontram-se expostos na Tabela 5.

Todos os modelos VAR foram estimados utilizando-se quatro defasagens a fim de verificar qual seria a mais adequada para explicar o modelo em questão. Deste modo, a seleção do número de defasagens dos modelos VAR foi realizada com base nos me-

3 Os resultados dos testes de raiz unitária divergiram quanto à ordem de integração das exportações de matérias-primas. Neste caso, o teste KPSS foi realizado e o resultado confirmou tal série como I(0). 
nores valores indicados pelos critérios de informação de Schwarz, sendo, portanto, adotado para todos os modelos uma defasagem.

Tabela 5 - Escolha das defasagens do VAR

\begin{tabular}{|c|c|c|c|c|}
\hline \multicolumn{5}{|c|}{ Modelo Alimentos } \\
\hline Defasagem & FPE & AIC & SC & HQ \\
\hline 1 & 2321053,00 & 28,84 & $30,07^{*}$ & 29,29 \\
\hline 2 & 1675451,00 & 28,46 & 30,72 & 29,29 \\
\hline 3 & $1256723,00^{*}$ & 28,05 & 31,32 & $29,25^{\star}$ \\
\hline 4 & 1606274,00 & $28,02^{*}$ & 32,32 & 29,61 \\
\hline \multicolumn{5}{|c|}{ Modelo Matérias Primas } \\
\hline Defasagem & FPE & AIC & SC & HQ \\
\hline 1 & 1382479,00 & 28,32 & $29,55^{*}$ & 28,77 \\
\hline 2 & $719474,70^{*}$ & $27,62^{*}$ & 29,87 & $28,45^{*}$ \\
\hline 3 & 1072413,00 & 27,89 & 31,16 & 29,09 \\
\hline 4 & 1191414,00 & 27,72 & 32,02 & 29,31 \\
\hline \multicolumn{5}{|c|}{ Modelo Minerais } \\
\hline Defasagem & FPE & AIC & SC & HQ \\
\hline 1 & 11380177,00 & 30,43 & $31,66^{*}$ & 30,88 \\
\hline 2 & $7567040,00^{*}$ & 29,97 & 32,22 & $30,80^{*}$ \\
\hline 3 & 9214161,00 & 30,04 & 33,31 & 31,25 \\
\hline 4 & 8592595,00 & $29,70^{*}$ & 34,00 & 31,29 \\
\hline \multicolumn{5}{|c|}{ Modelo Energia } \\
\hline Defasagem & FPE & AIC & $\mathrm{SC}$ & HQ \\
\hline 1 & 14155514,00 & 30,65 & $31,87^{*}$ & 31,10 \\
\hline 2 & 7140809,00 & 29,91 & 32,16 & $30,74^{*}$ \\
\hline 3 & 6995116,00 & 29,76 & 33,03 & 30,97 \\
\hline 4 & $6055262,00^{*}$ & $29,35^{*}$ & 33,65 & 30,94 \\
\hline
\end{tabular}

Notas: $\left(^{*}\right)$ Indica a defasagem selecionada para cada critério de informaçãa; FPE: Final prediction error; AIC: Akaike SC: Schwarz information criterion; HQ: Hannan-Quinn information criterion.

Fonte: Elaboraçăo própria com base nos resultados do Eviews 7.

Procedendo desta forma, os modelos estimados contaram com as seguintes especificações":

- Modelo Alimentos: VAR (1) = TCPIB, XAL, DTCREF, DIPAL, DYE

- Modelo Matérias-Primas: VAR (1) = TCPIB, XMP, DTCREF, DIPMP, DYE

- Modelo Minerais: VAR (1) = TCPIB, DXMIN, DTCREF, DIPMIN, DYE

- Modelo Energia: VAR (1) = TCPIB, DXEN, DTCREF, DIPE, DYE

4 Variáveis precedidas por D indicam que as mesmas foram utilizadas em primeira diferença na estimação do VAR.
Em adição, foram feitos testes de estabilidade do VAR (AR Roots Graph) e testes de autocorrelação serial (LM Autocorrelation), sendo que tais testes indicaram a ausência de autocorrelação na primeira defasagem e a estabilidade dos VAR em todos os modelos estimados, corroborando os resultados fornecidos pelo critério de Schwarz.

\subsection{FUNÇÕES DE RESPOSTA AOS IMPULSOS}

As funções de respostas aos impulsos (FIR) buscam averiguar a direção dos efeitos de uma inovação (choques) no tempo $t$ dos termos de erro de uma variável particular sobre os valores presentes e futuros das demais variáveis que compõem a estrutura endógena do VAR (Stock e Watson, 2001).

Considerando que as FIR são sensíveis em relação à ordem das variáveis inseridas no VAR, optou-se por estimar a Generalized Impulse-Response Function (GIR), ou seja as funções de resposta aos impulsos generalizadas, pois, neste caso, os resultados não são afetados pela ordenação das variáveis nos sistemas 5 .

No contexto deste trabalho, a estimação das funções de resposta aos impulsos generalizadas tem como objetivo avaliar a direção (positiva ou negativa) dos possíveis efeitos dos choques das exportações brasileiras de commodities sobre o comportamento da taxa de câmbio real efetiva e do processo de crescimento econômico.

Havendo evidências da maldição dos recursos naturais, espera-se observar dois canais de transmissão (efeitos) das exportações de commodities sobre o comportamento do produto e do câmbio:

- Efeito I: Os choques das exportações das diversas commodities devem exercer um efeito negativo sobre a taxa de crescimento do PIB. Esta seria uma evidência direta da contribuição da especialização da economia em bens intensivos em recursos naturais para o menor crescimento do produto. Este efeito se dá pelo fato de que os incentivos ligados aos preços e condições de demanda favoráveis aos produtos primários levaria ao deslocamento dos recursos produtivos para os setores produtores de commodities implicando menor produção de bens comercializáveis, com impactos prejudiciais sobre o crescimento.

- Efeito II: Os choques das exportações das diversas commodities devem exercer um efeito negativo sobre a taxa de câmbio real efetiva. Esta seria uma evidência indireta da maldição dos recursos naturais pela via da Doença Holandesa, na medida em que as divisas provenientes das vendas externas dos produtos pri-

5 Para mais informações, ver Pesaran e Shin (1998). 
mários conduziriam à apreciação cambial, prejudicando a indústria manufatureira e, em última instância, acarretando baixo crescimento econômico.

Deste modo, espera-se identificar se a especialização da estrutura exportadora da economia brasileira em determinadas commodities (alimentos, matérias-primas, minerais e energia) pode exercer respostas distintas da taxa de câmbio real (apreciação ou depreciação), além de se verificar se o incentivo para a migração de recursos para os diversos setores intensivos em recursos naturais teriam efeitos diferentes (maior ou menor capacidade) para estimular o crescimento do produto.

As Figuras 1 a 4, apresentadas na sequência, exibem os resultados das funções de resposta aos impulsos generalizadas (GIR) para cada um dos modelos analisados: alimentos, matérias-primas, minerais e energia relacionados às respostas da taxa de crescimento do PIB e da taxa de câmbio real efetiva ${ }^{6}$.

\section{Figura 1 - Resultados da GIR para o Modelo de Alimentos}
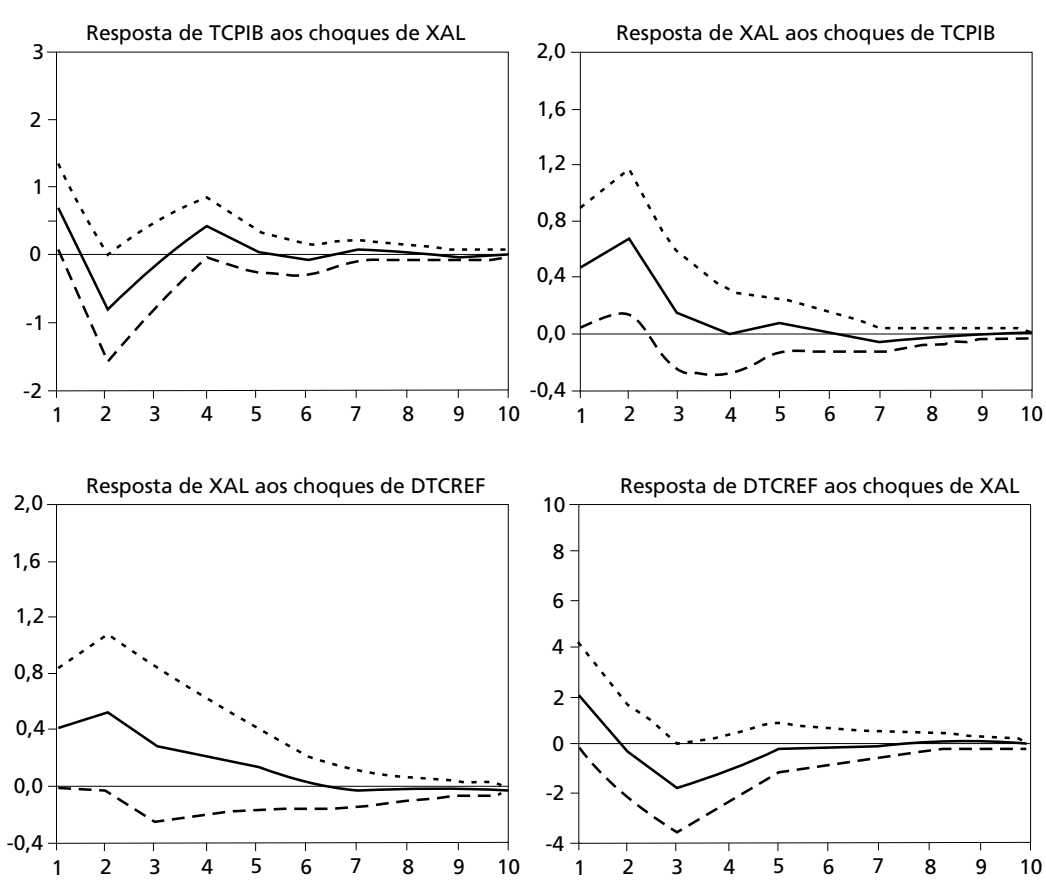

Fonte: Elaboração própria com base nos resultados do Eviews 7 .

6 De acordo com os objetivos deste trabalho, a apresentação dos resultados da GIR será restrita aos resultados para a resposta da taxa de crescimento do PIB e da taxa de câmbio real em relação aos choques das exportações das diversas commodities.
Figura 2 - Resultados da GIR para o Modelo de Matérias-Primas
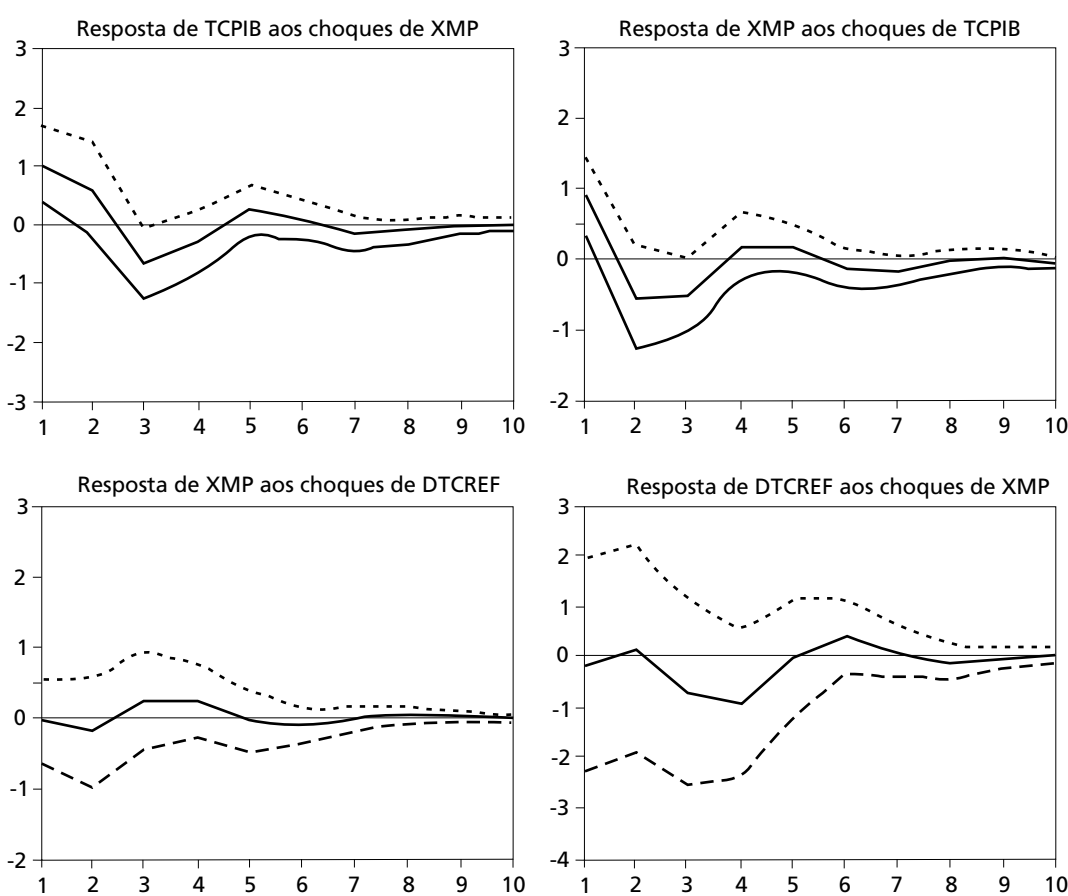

Fonte: Elaboração própria com base nos resultados do Eviews 7 .

Para o modelo de alimentos (Figura 1), as evidências indicam que a taxa de crescimento do PIB responde de forma negativa aos choques das exportações de alimentos com uma defasagem (após um trimestre) (Efeito I). Também se percebe uma resposta negativa da taxa de câmbio real efetiva aos choques das exportações de alimentos após o primeiro trimestre do choque (Efeito II). Neste sentido, é possível intuir alguma evidência da maldição dos recursos naturais na economia brasileira, já que o aumento das exportações de alimentos parece colaborar para um menor crescimento do produto e para uma apreciação cambial, embora esses efeitos sejam defasados e se dissipem rapidamente ao longo do tempo.

De outro lado, verifica-se que as exportações de alimentos têm uma resposta positiva aos choques do crescimento do produto e da taxa de câmbio real efetiva, indicando que o bom desempenho da economia e a depreciação cambial parecem favorecer a especialização das exportações em produtos alimentícios.

Para o modelo de matérias primas (Figura 2), obtém-se uma resposta negativa, embora com maior defasagem temporal (após dois trimestres) e com curta duração, 
da taxa de crescimento do PIB aos choques das exportações destes bens (Efeito I). Já as exportações de matérias primas favorecem conduzir à apreciação da taxa de câmbio real efetiva (resposta negativa) após o primeiro trimestre do choque (Efeito II), sendo que tal efeito também se dissipa rapidamente no tempo.

Os choques da taxa de crescimento do PIB favorecem as exportações de matérias primas apenas no primeiro trimestre. A partir do segundo, o maior crescimento da economia parece relacionado à menor especialização da pauta exportadora neste tipo de produto, mas tais efeitos se dissipam após o quinto trimestre do choque. As exportações de matérias primas se mostram pouco sensíveis aos choques da taxa de câmbio real efetiva.

Figura 3 - Resultados da GIR para o Modelo de Minerais
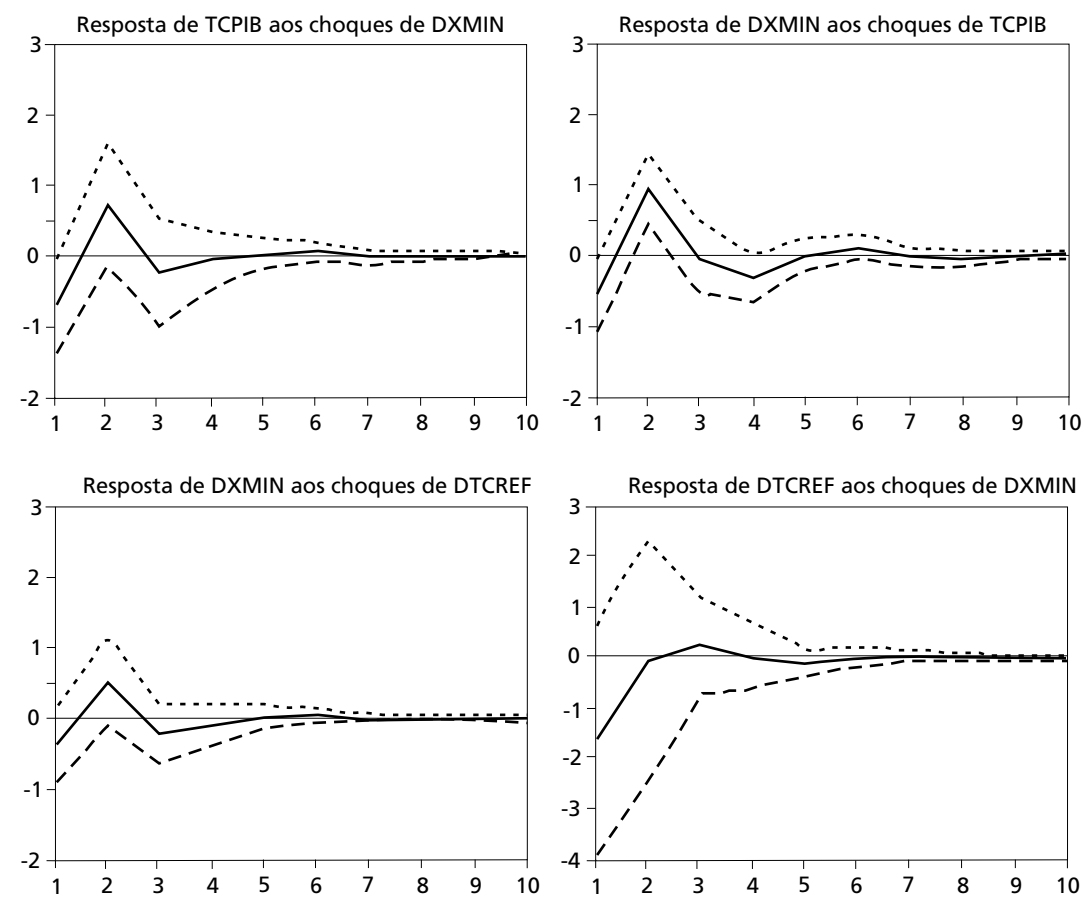

Fonte: Elaboraçăo própria com base nos resultados do Eviews 7 .

No que se refere ao modelo de minerais (Figura 3), a resposta da taxa de crescimento do PIB em relação aos choques das exportações de minerais (Efeito I) é inicialmente negativa, sendo revertida rapidamente (segundo trimestre), dissipando-se ao longo do tempo. Todavia, a taxa de câmbio real responde negativamente (apreciação) aos choques das exportações das commodities minerais (Efeito II). Este resultado dura apenas até o segundo trimestre, a partir do qual o efeito desaparece.

Já as exportações de minerais respondem negativamente tanto aos choques do crescimento econômico quanto da taxa de câmbio real efetiva. Porém, esses efeitos são revertidos no segundo trimestre e se esvaem rapidamente. Desta forma, o melhor desempenho da economia e a depreciação cambial se mostram atrelados à especialização das exportações em minerais, embora tais resultados sejam muito restritos ao curto prazo (primeiro trimestre após o choque).

Por último, no modelo das commodities energéticas (Figura 4), nota-se uma resposta negativa da taxa de crescimento do PIB aos choques das exportações destes bens após o segundo trimestre (Efeito I), porém este resultado é de pequena magnitude e se dissipa rapidamente no tempo. Já a taxa de câmbio real efetiva responde positivamente aos choques das exportações das commodities energéticas, o que sugere que a especialização em tais bens não se relaciona à apreciação cambial.

As exportações de commodities energéticas têm uma resposta inicial positiva aos choques da taxa de crescimento do PIB, mas este efeito é revertido a partir do segundo trimestre. Isto denota que o estímulo do crescimento econômico para alavancar as exportações daqueles bens é de curta duração. De outro lado, os choques da taxa de câmbio real impactam negativamente na especialização das exportações em itens de energia. Deste modo, uma depreciação cambial desestimula a especialização da economia na exportação de bens energéticos (reduz a participação destes itens na pauta exportadora).

Em síntese, estes resultados sugerem algumas evidências preliminares, embora fracas, da maldição dos recursos naturais na economia brasileira, uma vez que a especialização da pauta comercial em commodities parece contribuir para a obtenção de menores taxas de crescimento do PIB, especialmente, no caso dos alimentos e das matérias-primas (com defasagem temporal e curta duração), e dos minerais (restrito ao curto prazo). Isto sugere que a relação entre abundância em recursos naturais e crescimento econômico para o caso brasileiro depende do tipo de commodity analisada.

As evidências indiretas (embora também fracas) da maldição dos recursos naturais pela via da taxa de câmbio real (Doença Holandesa) são percebidas, com exceção dos produtos de energia. Assim, uma elevação das exportações de alimentos, matérias primas e minerais parece contribuir para o movimento de apreciação cambial. Mas estes efeitos também foram distintos para cada tipo de commodity: no caso dos minerais, percebe-se uma apreciação cambial mais significativa e imediata, enquanto para os alimentos e as matérias primas, este resultado se revela com uma alguma defasagem temporal e tem curta duração. 
Figura 4 - Resultados da GIR para o Modelo de Energia
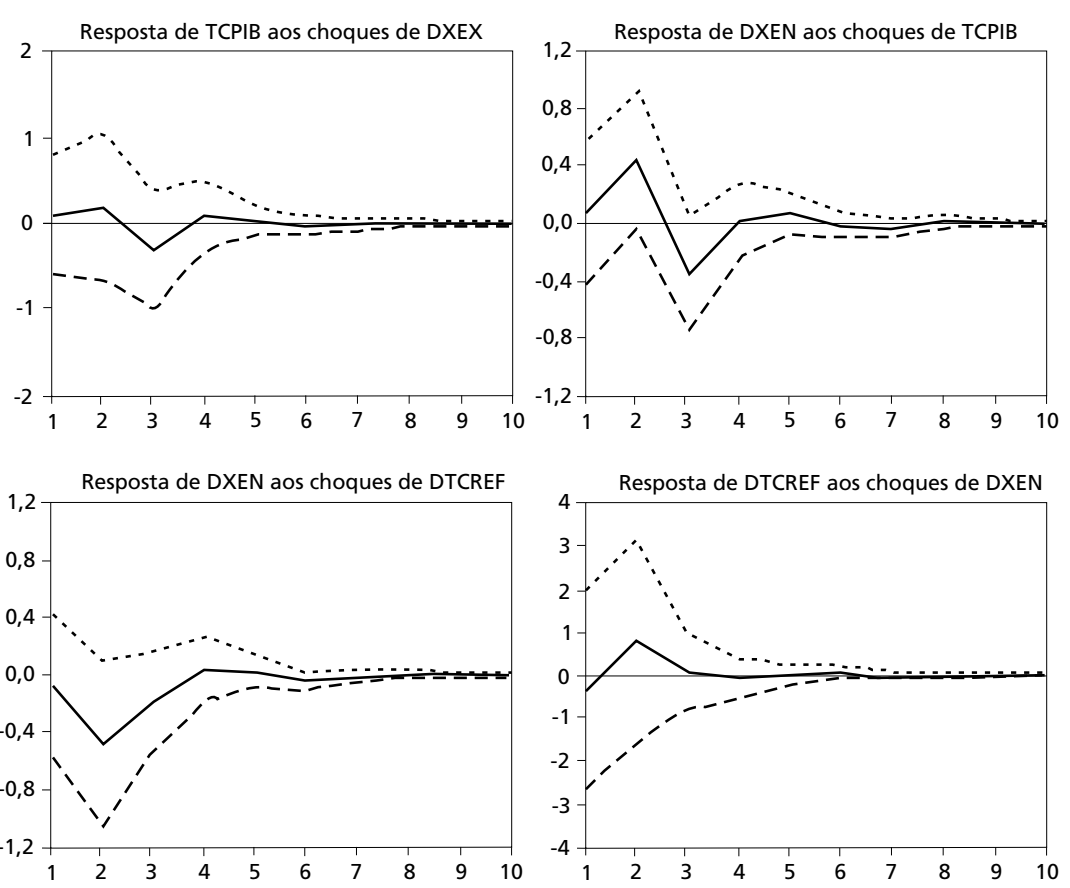

Fonte: Elaboração própria com base nos resultados do Eviews 7.

\section{CONSIDERAÇÕES FINAIS}

O padrão de especialização das economias em bens intensivos em recursos naturais tem sido discutido pela literatura econômica, tendo em vista os efeitos destes produtos sobre o comportamento do crescimento econômico. Nestes termos, alguns estudos argumentam que características estruturais das economias centradas na abundância de recursos naturais tendem a promover uma ineficiência na utilização destes recursos e atitudes rent-seeking, que prejudicam o processo de investimento e crescimento econômico. Outros estudos abordam que a especialização da estrutura produtiva e exportadora em commodities, nas quais certos países possuem vantagens comparativas, pode causar apreciação da taxa de câmbio real, o que acaba prejudicando o desenvolvimento dos setores produtores de bens manufaturados, que perdem competitividade no cenário internacional em virtude do câmbio apreciado. Em consequência, o perfil das exportações em commodities colabora para a obtenção de menores taxas de crescimento econômico no longo prazo, em virtude do menor conteúdo tecnológico e do baixo valor agregado destes bens quando comparados aos produtos industriais. Levando em consideração tais pressupostos, alguns trabalhos encontram evidências de que países ricos em recursos naturais, especialmente petróleo e minerais, possuem menores taxas de crescimento econômico no longo prazo ("maldição" dos recursos naturais).

Os dados do comércio de commodities negociadas pela economia brasileira no período 2000-2011 revelam que estes produtos tiveram uma participação crescente nas vendas externas do país, e obtiveram um saldo comercial bastante favorável. A maior participação das commodities no total exportado ocorreu de forma generalizada, pois tanto alimentos, matérias-primas, minerais e combustíveis ganharam maior peso na pauta exportadora no período analisado. Ademais, verificou-se um avanço das commodities no conjunto dos 15 principais produtos exportados pelo país, com destaque para itens de minerais e de energia. Tais indícios sugerem que os produtos intensivos em recursos naturais são preponderantes na determinação dos resultados comerciais da economia brasileira, embora a observação das parcelas das exportações em níveis mais desagregados permita ressaltar que a pauta comercial se mantém relativamente diversificada, não sendo possível identificar uma dependência significativa das exportações em relação a um ou poucos tipos de bens. Além disso, pode-se perceber que a conjuntura internacional favorável em termos das variações positivas dos preços internacionais das commodities e da demanda externa foram fatores relevantes para determinar o comportamento das exportações de commodities.

Este trabalho estimou modelos baseados na metodologia de Vetores Auto-Regressivos (VAR) e Funções de Resposta aos Impulsos Generalizadas (GIR) para investigar as relações entre a especialização das exportações de alimentos, matérias-primas, minerais e energia sobre o crescimento da economia brasileira, e os efeitos daquelas commodities sobre a taxa de câmbio real, tomando por base o período 2000-2011.

Os resultados sugerem a importância da análise das commodities em níveis desagregados para se explicar o comportamento da taxa de câmbio real e do crescimento econômico brasileiro. Isto pode ser justificado pelo fato de que a pauta das exportações brasileiras de commodities apresenta-se relativamente diversificada, portanto, a análise do total exportado de bens intensivos em recursos naturais pode obscurecer a relevância ou o comportamento distinto de uma ou mais categorias de produtos.

Deste modo, obteve-se algum papel das exportações de alimentos, matérias-primas e minerais para explicar o desempenho menos favorável da taxa de crescimento do produto brasileiro, em linha com os argumentos da maldição dos recursos naturais No entanto, tais evidências são pouco robustas, pois ocorrem com defasagem e têm curta duração para os dois primeiros produtos, e fica restrito ao curto prazo (primeiro trimestre) no caso dos minerais. Em adição, foram obtidas evidências (fracas) de que tais produtos (exceto energia) foram relevantes para explicar a apreciação da taxa de câmbio real brasileira. 
Sendo assim, identifica-se que as categorias de commodities têm papéis diferenciados em relação aos seus efeitos sobre as variáveis macroeconômicas (PIB e câmbio). De todo modo, tendo em vista as recomendações da literatura sobre a relação entre perfil exportador e crescimento econômico, cumpre sinalizar a necessidade de mudanças estruturais na economia brasileira, que determinem uma reestruturação da pauta de exportações na direção de produtos de maior conteúdo tecnológico e valor agregado, se as autoridades brasileiras desejam estimular taxas de crescimento econômico mais elevadas e sustentadas ao longo do tempo.

\section{REFERÊNCIAS}

BANCO CENTRAL DO BRASIL (BCB). Séries Temporais. [On-line] Banco Central do Brasil, Economia e Finanças. Disponível em: <http://www4.bcb.gov.br/?SERIESTEMP>. Acesso em: ago. 2012.

BRESSER-PEREIRA, L. C. “A Doença Holandesa” In. BRESSER-PEREIRA, L. C. Globalização e Competição: Por que alguns países emergentes têm sucesso e outros não. Rio de Janeiro: Elsevier, 2009, p. 141-171.

BRESSER-PEREIRA, L. C.; MARCONI, N. Existe Doença Holandesa no Brasil? In: FÓRUM DE ECONOMIA DA FUNDAÇÃO GETÚlIO VARGAS, 4, Escola de Economia de São Paulo, São Paulo, SP, 17-18 set. 2007. Disponível em: <http://www.bresserpereira.org.br/papers/2008/08.14.Existe.doen\%C3\%A7a.holandesa.comNelson.Marconi.5.4.08.pdf>. Acesso em: out. 2008

CARDOSO, E.; HOLLAND, M. South America for the Chinese? A trade-based analysis. Paris: OECD, 2009.

COLLIER, P.; GODERIS, B. Commodity prices, growth and the natural resources curse: reconciling a conundrum. Working Paper, Centre for the Study of African Economies, n. 276, ago. 2007.

CORDEN, W. M. Booming sector and Dutch disease economics: survey and consolidation. $O x$ ford Economic Papers, v. 36, n. 3, p. 359-380, nov. 1984.

CORDEN, W. M.; NEARY, J. P. Booming sector and de-industrialization in a small open economy. Economic Journal, v. 92, n. 368, dez. 1982.

ENDERS, W. Applied Econometric Time Series. 2 ed. New York: Wiley, 2004.

FRANKEL, J. The natural resource curse: a survey. NBER Working Paper, n. 15836, mar. 2010. Disponível em: <http://www.nber.org/papers/w15836>. Acesso em: nov. 2011.

FUNDO MONETÁRIO INTERNACIONAL (FMI). International Financial Statistics Database. Washington, DC: CD-ROM, Jun. 2012.

LEDERMAN, D.; MALONEY, W. F. In Search of the Missing Resource Curse. Policy Research Working Paper, World Bank, Washington, n. 4766, nov. 2008. Disponível em: <http://www-wds.worldbank.org/servlet/WDSContentServer/WDSP/IB/2008/11/04/ 000158349_200 81104085814/Rendered/PDF/WPS4766.pdf >. Acesso em: nov. 2011.
MINISTÉRIO DO DESENVOLVIMENTO, INDÚSTRIA E COMÉRCIO EXTERIOR (MDIC). Balança comercial mensal. [On-line] MDIC, Estatísticas de comércio exterior - DEAEX. Disponível em: $<$ http://www.desenvolvimento.gov.br/sitio/interna/interna.php?area=5\&menu=1161 $>$. Acesso em 20 ago. 2012.

MEHLUM, H.; MOENE, K.; TORVIK, R. Institutions and the resource curse. The Economi Journal, v. 116, p. 1-20, jan. 2006.

MURSHED, S. M. When does natural resource abundance lead to a resource curse? Discussion Paper, n. 04-01, mar. 2004. Disponível em: <http://www.landecon.cam.ac.uk/up211/EP09/ reading/session1/Murshed_2004.pdf $>$. Acesso em: nov. 2011.

NAKAHODO, S. N.; JANK, M. S. A Falácia da "Doença Holandesa" no Brasil. Documento de Pesquisa. São Paulo: Instituto de Estudos do Comércio e Negociações Internacionais, mar. 2006

PALMA, J. G. Quatro fontes de "desindustrialização" e um novo conceito de "Doença Holandesa”. In: CONFERÊNCIA INDUSTRIALIZAÇÃO, DESINDUSTRIALIZAÇÃO E DESENVOLVIMENTO. FIESP e IEDI. Ago. 2005.

PAPYRAKIS, E; GERLAGH, R. The resource curse hypothesis and its transmission channels. Journal of Comparative Economics, n. 32, p. 181-193, 2004.

PESARAN, H. H.; SHIN, Y. Generalized impulse response analysis in linear multivariate models. Economics Letters, v. 58, n. 1, p. 17-29, jan. 1998.

PESSOA, A. Natural resources and institutions: The "natural resources curse" revisited. MPRA Paper, Faculdade de Economia da Universidade do Porto, n. 8640, mai. 2008. Disponível em: <http://mpra.ub.uni-muenchen.de/8640/>. Acesso em: nov. 2011

PLOEG, F. V. D. Natural resources: curse or blessing? CESIFO Working Paper, n. 3125, jul. 2010 Disponível em: <http://papers.ssrn.com/sol3/papers.cfm?abstract_id=1640462〉. Acesso em: nov. 2011.

ROCHA, F. Natural resource curse and externalities from natural resource exports. Texto pare Discussão, Instituto de Economia, Universidade Federal do Rio de Janeiro, n. 2903, nov. 2010. Disponível em: <http://www.ie.ufrj.br/datacenterie/pdfs/seminarios/pesquisa/ texto2903.pdf>. Acesso em: out. 2012.

SACHS, J. D.; WARNER, A. M. The Curse of Natural Resources. European Economic Review, Harvard University, Cambridge, n. 45, p. 827-838, 2001.

SACHS, J. D.; WARNER, A. M. Natural resource abundance and economic growth. NBER Working Paper, n. 5398, dez. 1995. Disponível em: <http://www.nber.org/papers/w5398>. Acesso em: out. 2008.

STIJNS, J. C. Natural resource abundance and economic growth revisited. Working Paper, Northeastern University, Boston, n. 05-002, 2001. Disponível em: <http://www.economics.neu. edu/papers/documents/05-002.pdf >. Acesso em: nov. 2011.

STOCK, J.; WATSON, M. Vector Autoregression. Journal of Economic Perspectives, v. 15, n. 4 , mar. 2001 